\title{
The Role of International Adjudicative Bodies in Prosecuting Genocide Crime: A Case Study of International Criminal Tribunal for the Former Yugoslavia (ICTY)
}

\author{
Joko Setiyono* and Kholis Roisah
}

Diponegoro University, Semarang, Indonesia

\begin{abstract}
This paper is intended to explain the urgency of the formation of the International Criminal Tribunal for the former Yugoslavia (ICTY), as an ad hoc international court based on United Nations Security Council (UNSC) Resolution No. 827 of 1993, to try perpetrators of genocidal crimes against ethnic Bosnian Muslims. The crime of genocide originated from the ethnic conflict that occurred in the federation of Yugoslavia. The research was conducted by using a qualitative method, based on analysis of data sourced from international journals, books, and other electronic sources. The results conclude that the genocide that occurred against Bosnian Muslim ethnicity is one form of international crime while threatening international peace and security in the Balkan region, also intended to break the practice of impunity against international criminals who are a common enemy of humanity (hostis humans generis). These two considerations form the legal basis for the issuance of the UNSC Resolution on the Establishment of ICTY. The establishment of ICTY as an international court is intended as a court used to try perpetrators of genocidal crimes against Bosnian Muslim ethnicities, so that similar crimes will not be repeated in the future, both in Yugoslavia and in various other countries.
\end{abstract}

Keywords: ICTY, International Court of Justice, Genocide Crime, United Nations, hostis humanis generis.

\section{INTRODUCTION}

Historical facts show that Yugoslavia is a country that is currently divided into several states in the Eastern European region. Central Intelligence Agency (CIA) data indicate that in 1987, where Yugoslavia still stood with the capital of Belgrade, it first appeared in 1918 under the names of the Kingdoms of Serbia, Croatia, and Slovenia. In its development, the Kingdom must end due to World War II, where Germany was able to invade the land of the Yugoslavia region (Jessup, 1989; Horton et al., 1998; Allcock, 2000). After the end of World War II, Yugoslavia reunited for the important role of Joseph Broz Tito (Arnold \& Wiener, 2012). The name Yugoslavia itself is taken from the name of its people namely South Slavia where after centuries this region became the Ottoman Empire and Austria-Hungary (CIA, 2016). Geographically, Yugoslavia has a fairly large territorial area, which is $255,800 \mathrm{~km} 2$ with details of $255,400 \mathrm{~km} 2$ of land area and $400 \mathrm{~km}^{2}$ of sea area. Climatic conditions that take place in Yugoslavia with relatively hot and dry temperatures and when the summer feels warm due to the rain. Apart from disasters, the problem that often occurs in Yugoslavia is earthquakes with quite high frequency. Orthodox Christianity became the majority religion of the Yugoslav population of $50 \%$, followed by Catholicism $30 \%$ and Islam $10 \%$. Some of the major

*Address correspondence to this author at the Faculty of Law, Diponegoro University, Jl. Prof. Soedarto, S.H. Tembalang, Semarang, Central Java 50275, Indonesia; Tel: +62-2476918201; Fax: +62-247691820;

E-mail: jokosetiyono@lecturer.undip.ac.id ethnicities that inhabit this federation state include the Serbs, the Bosniacs, and the Croats (Huntington, 1996).

It is worth mentioning that in terms of government, the system adopted by Yugoslavia is communism and has made it one of the communist countries in the world. Communism in the country of Yugoslavia had nothing to do with ideological wars like those waged by the Soviet Union and the United States at that time. In this case, the Yugoslav state took a position not to act in the ideological war and instead initiated a nonaligned movement to resolve the remnants of problems related to decolonization and also strive to uphold world peace. The complexity of the conflict that occurred in Yugoslavia was partly due to the successful maneuvering of Mladic forces in carrying out massacres of refugee camps. After the leadership of Josep Broz Tito in Yugoslavia, instability was everywhere. Yugoslavia which consists of various states with different characters and cultures wants their respective independence by claiming strategic areas. The instability that occurred at least resulted in a crisis of economic growth, divisions in politics in government, to the occurrence of prolonged inter-ethnic friction that led to inter-ethnic conflict in Yugoslavia (Stavrianos, 2000).

The territory of Bosnia Herzegovina at that time became a contested area by Serbia and Yugoslavia. Bosnians, who are predominantly Muslim, have a special area where Islamic culture is very close to daily 
life. This is certainly the opposite of the majority of other states in Yugoslavia. Therefore, when the community of European countries recognized the Bosnian region as an area of independent integrity, the Serb and Croat separatists at that time wanted an attack on Muslims in Sarajevo, the capital of Bosnia Herzegovina. The joint Serbian armed forces and Mladic's Yugoslav troops, then Srpska, on 5 April 1992 to coincide with independence day, carried out a siege in the heart of the capital, Sarajevo. As Army Chief of Staff, Mladic felt he had the power to cancel the referendum on independence by occupying the seat of government, with the longest siege in history. Under these conditions, various humanitarian assistance was channeled into Bosnian territory, including a package of peacekeeping troops, to guard the area of refugee camps carried out by the United Nations (McMahon, 2004).

The events above, it is not surprising if it becomes very large, because Mladic's indiscriminate command can cut down his military opponents including innocent civilians. Precisely, on July 6, 1995, the camp in the Srebrenica region was a safe area for refugees to get all the necessities that had become a problem because of the siege crisis. As a result of the blind attack from the Mladic command, it also destroyed the UN peacekeeping troops who were on guard, where at least there were 400 Dutch troops (Donia, 2014). The people who were in the camp, then separated between men and women to be brought to the field, to carry out an act of mass murder. Ratko Mladic had a hand in giving orders to his armed forces to carry out missions that ended up in court on charges of genocide. In 19921995 it was known that Ratko Mladic became an actor behind the scenes in a major action, which involved several states, namely Bosnia Herzegovina, Croatia, and also Kosovo (Gibbs, 2012). It is noteworthy that these brutal actions also dragged the Serbian leader at the time, Slobodan Milosevic, who was allegedly involved in Mladic's defense case in court and helped protect the form of a hiding place that was difficult to detect by the International Criminal Police Organization (ICPO). This paper aims to investigate the urgency of ICTY as international justice formed by the united nations in prosecuting crimes for genocide on Bosnian ethnicity. This paper is intended to explain the urgency of the formation of the International Criminal Tribunal for the former Yugoslavia (ICTY), as an ad hoc international court based on United Nations Security Council (UNSC) Resolution No. 827 of 1993, to try perpetrators of genocidal crimes against Bosnian Muslims.

\section{LITERATURE REVIEW}

The International Court of Justice is one of the main structures of the United Nations in resolving disputes in the international sphere. The International Court of Justice, domiciled in The Hague in the Netherlands, has the main task of resolving international disputes through judicial settlement. The International Court is an independent judiciary, which does not take sides with anyone involved in a case being handled. An international dispute is a situation when two countries have conflicting views regarding whether or not the obligations contained in the agreement are carried out. International disputes include inter-state and state, state and individual, state and foreign corporations, and disputes between countries and non-state states. Disputes between countries are disputes that do not affect international life and can also dispute that threaten international peace and involvement.

On the other hand, the International Court of Justice regulates international disputes with the aim that these disputes can be resolved as early as possible honestly and fairly independently. Arrangements for dispute resolution are contained in International Customary Law, The Hague Convention I of 1899 and 1907 concerning Peaceful Settlement of Disputes and the UN Charter (Jones, 2013). The Charter stipulates that the establishment is intended to facilitate the peaceful settlement of disputes between countries, through the International Court of Justice. Also, a dispute cannot be said to be an international dispute if the settlement does not affect the relations of the two parties.

\section{METHOD}

The writing of this paper uses a qualitative method, based on analysis of data sourced from international journals, books, and other electronic sources. The approach used is nondoctrinal law research. Generally, the research investigates the role of International Adjudicative Bodies in Prosecuting Genocide Crime. The object was the trial of genocide crime by taking a case study of the International Criminal Tribunal Former Yugoslavia (ICTY). In this context, the important consideration was an ad-hoc international tribunal based on the Resolution of the UN Security Council under the International Criminal Tribunal Former Yugoslavia (ICTY). The establishment of ICTY is intended as a means to prosecute perpetrators of genocidal crimes included in one of the gross violations of human rights categories. The analysis was focused on the principle in international law of hostis humanis 
generis by using two main considerations: threatening international peace and security and breaking the practice of impunity against international criminals who are a common enemy of humanity (hostis humanis generis).

\section{RESULTS}

In the late 19th and early 20th centuries, the vulnerability of ethnic minority and religious groups to the threat of genocide was very high. According to Article II of the UN Convention on the Prevention and Punishment of Crimes for Genocide explains that genocide means the following actions carried out with the intent to destroy, in whole or in part, national, ethnic, racial, or religious groups (Jones, 2013). This is influenced by the unstable political turmoil that causes certain groups to try to come to power. The reaction of the international community to genocide in Bosnia is very complex. That is because, after the Cold War, international political conditions in the world were in a vulnerable condition, with a shift in world governance caused by the fall of the Soviet Union. The international community is seen as failing to mitigate and cope with conflict, because of its slow response and only as an observer. Furthermore, before we review what forms of response the international community has taken, it is better to first understand what is meant by the international community. The international community is several abstract actors who have their interests and agendas and have different levels of power and power in the current world order. How active an actor is depended on their interests in trying to overcome or mitigate the conflict in Bosnia. Therefore, several actors must be known to have an important role in handling the conflict, namely the United Nations, the United States (US), European Community (EC), NATO, and several other international organizations.

The main reason why the international community has been slow in responding to the conflict in Bosnia, is due to the lack of mass media covering the case, although many international journalists monitor this case. Bosnia is not considered an urgent issue for major powers and is a major factor why the US does not react quickly to events that they usually deal with quickly. Over time, where the conflict escalated, the international community began to realize it, but it was still not the US that took over, but the EC. The ethnic conflict that occurred in Bosnia was the first challenge to EC foreign policy. It is unfortunate, that from the beginning the EC had underestimated the level of conflict and viewed it as a civil war between three parties based solely on ethnic and racial differences, and did not consider it an international conflict that had a political dimension between the three parties (Bassiouni, 2011). Also, in its implementation, the EC was considered ineffective, because its bureaucracy was considered slow and instead counterproductive to the peace process. The number of internal problems in the EC shows that this organization is not ready to face the conflict, where member countries are still busy taking care of their respective national interests. Another thing that should be stated is that the mindset that states diplomacy is more than enough to resolve conflicts so that in general the EC only offers diplomatic solutions to the parties involved in the conflict. Excessive trust in diplomacy also makes them stop all efforts of the UN or other international communities to intervene through embargoes or directly.

After a while, the US was passive on the Bosnian issue, beginning to be moved to intervene and end the conflict. It began at the end of Bush's administration, but could only be fully implemented since the beginning of President Bill Clinton's administration. US diplomat Richard Holbrooke stated that "Bosnia will be the key test of US policy in Europe. We must therefore succeed in whatever we attempt" (Holbrooke, 2011; Gibbs, 2012). The statement shows that the US has begun to consider Bosnia as an urgent issue. US intervention on the conflict, also based on political interests, in this case, to strengthen its hegemony in Europe and strengthen and seek new functions for NATO after the fall of the Soviet Union after the Cold War (Gibbs, 2012; Fleming, 2016).

After a long hesitation in determining the best steps to defuse conflict, the first step taken by the US was to deny the division of regions to the parties involved in the conflict. The proposal, called the Vance-Owen Peace Plan, will divide Bosnia into three regions, namely $43 \%$ given to the Serbs, $32 \%$ given to the Croats, and $25 \%$ given to the Muslims. The reason why the US actively rejected this was that they assumed that if they gave $43 \%$ to the Serbs (whose population was only around $31 \%$ of Yugoslavia at the time) that meant they would only meet demands from Serbian aggression. The US action was considered to be very slow in reducing the conflict, especially only two years later through the Dayton Peace Accords, the US finally allowed the distribution of power in Yugoslavia, giving $49 \%$ of land to the Serbs, despite having to call on NATO to carry out airstrikes to the militants (Konseska, 2014). 
In addition to the two actors mentioned above (US and EC), another actor who can be considered as the international community involved in handling the conflict is the United Nations. The initial UN began to be active after the concentration camps were discovered and disseminated, which in August 1992 condemned ethnic cleansing and in September sent UNPROFOR (United Nations Protection Force) troops to conflict areas. Through UNPROFOR, the UN is trying to protect and make a safe area for refugees, but it turns out that UN forces are still too little to protect refugees from attacks by other parties, so that the area cannot protect victims in conflict areas (Genser \& Ugarte, 2014). The UN failure in the Bosnian conflict was the Srebrenica massacre, in which more than 8,000 Bosnians, both young and old, were slaughtered in the city. The perpetrators of the massacre, Ratko Mladić ordered Serbian republican troops to attack and massacre everyone in the city. The driving force behind the massacre was the failure of the UN to disarm the Serbian army, as well as its failure to secure and protect Bosnian refugees from outside attacks. Srebrenica's genocide has had a huge impact on the international community. In May 1993, the UNSC based on the Resolution that was issued formed the International Criminal Tribunal for the Former Yugoslavia (ICTY) to prosecute perpetrators of genocidal crimes that had occurred in Yugoslavia. As a note, it is worth mentioning that although the ICTY has been formed and carried out its trials, it is still considered unable to have a positive impact or sense of peace for the people of the Yugoslav state for ethnic conflicts that have led to genocide crimes against Bosnian Muslims.

According to the International Criminal Court, international crimes which become their absolute competence as stipulated in the 1998 Rome Statute include crimes of genocide, crimes against humanity, war crimes, and crimes of aggression (Schillings, 2016; Harding, 2007). The judicial process is divided into two stages, namely the investigation stage and the prosecution stage, and it should be noted that during the judicial process, the principles of existing criminal law must also be acknowledged. In the case that occurred in Yugoslavia, where one of the crimes committed was a form of genocidal crime, where the perpetrators killed 8,000 Bosnian Muslims as a minority. The perpetrators of genocide are considered to have violated the Geneva Conventions of 1949 as one of the instruments in International Humanitarian Law, which is intended to provide international protection against victims of war or armed conflict, both combatants and civilians.

It is worth mentioning that besides Ratco Mladic, other military leaders have been arrested and tried for their involvement in the massacre of Bosnian Muslims, including Tihomir Blaskic, former commander of the Croatian Defense Council. He was charged with a series of atrocities against Bosnian Muslims between May 1992 and January 1994 in Bosnia Herzegovina, specifically in the Lasva Valley region. In his capacity as commander of the Croatian Bosnian force, he was charged with 6 types of gross human rights violations as stipulated in the 1949 Geneva Convention, Article 2 of the ICTY Statute, 11 types of violations of war habits, and 3 types of crimes against humanity, including persecution, illegal attacks on civilians and their property, holding civilians hostage, willful killing, deliberately causing serious suffering or serious bodily injury, murder, inhumane treatment, and destruction and seizure civilian property. Besides, there is also Zlatko Aleksovski, the suspect is the prison commander (prison facility) which regulates prison facilities for Bosnian civil society prisoners in Kaonik, Bosnia, and Herzegovina. He was accused of carrying out a series of outrages over human dignity, related to his responsibilities as individuals and superiors. Aleksovsko was arrested by the Croatian authorities on 6 June 1996 to be submitted to ICTY as an international judicial institution established under the UNSC Resolution. Aleksocski is considered to have violated 3 categories of war crimes, including: (1) grave violations of the 1949 Geneva Convention as stipulated in Article 2 letter b, Article 7 paragraph (1), and (3) ICTY Statute in the form of inhumane acts; (2) Serious violations of the 1949 Geneva Convention provided for in Article 2 letter c, Article 7 paragraph (1) of the ICTY Statute in the form of intentionally causing serious suffering or bodily injury or serious health problems; (3) Violations of laws and customs of war as regulated in Article 3, Article 7 paragraph (1) and (3) of the ICTY Statute in the form of harassment of one's dignity. Aleksovski was found guilty of the first two charges because the ICTY case review panel argued that the two indictments must be fulfilled with important elements that were strongly attached to the violations, namely violations must be committed against persons or property protected by each convention (Bergholtz, 2013).

In contrast to Mladic where he was discovered after the Bonia Muslim massacre, escaping and hiding for 14 years by moving his residence in a military resort 
owned by his comrades in arms who considered Mladic a hero and not a war criminal. For 14 years Mladic's whereabouts are unknown because the Slobodan Milosevic government at the time denied the accusations of protecting Mladic. After the end of Slobodan Milosevic's government, Yugoslavia decided to separate, due to frequent internal conflicts within the state. This resulted in Mladic's security being threatened and the Serbian police decided to arrest him in 2002 (Moffett, 2012). It is worth mentioning that during a gun battle, Mladic was able to escape, and only later in 2011 was captured by a special Serbian police unit and taken to the ICTY to be tried for crimes he had committed.

\section{DISCUSSION}

The crimes committed by the Serbian forces are very inhumane and violate applicable international law. Cruelty in all cases is carried out so quickly and caused many casualties. The cases committed by Ratko Mladic make the world concerned because the actions he did have harmed many parties. The actions taken by Ratko Mladic were considered the cruelest acts carried out in Europe after World War II. All reactions from the international community and the International Court of Justice appeared to contribute to the response to the case. The response to the settlement of the case was already there, but Ratko Mladic managed to avoid the attempt to resolve the case.

As an explanation that there is already an ICTY formed to try perpetrators of crimes and gross human rights violations in Bosnia. However, Ratko Mladic was indicated to be assisted by the Government of Serbia, namely Slobodan Milosevic. Milosevic is suspected of protecting Ratko Mladic from justice by providing strict security in the city of Belgrade. Rebuttal from Milosevic against the allegations, and did not rule out the possibility of a lot of suspicion from the public. Ratko Mladic still feels safe under Milosevic's embrace. Shortly thereafter, the ICTY issued an arrest warrant for Milosevic for the murder, ill-treatment, and forcible deportation of Albanian civilians during the Kosovo War (Rodman, 2019). That way Ratko Mladic no longer gets close supervision and protection. From here the international world has hope and sees great opportunities in capturing and prosecuting Ratko Mladic.

The impetus for the arrest of Ratko Mladic was strengthened by the election of President Boris Tadic in Serbia. Boris Tadic won the elections in Serbia in 2008 which came from the democratic party (Palvlovic, 2013). Boris Tadic's government lasted for 4 years, namely from 2008-2012. Spanned his term of office, Boris Tadic always made efforts to arrest Ratko Mladic. On the other hand, in running the government in Serbia, Boris Tadic is known as a person who is proEuropean Union and pro-balance of relations between Serbia, Russia, and the US. The search and effort to capture Ratko Mladic were very intensive, namely by forming a special unit. Besides, Serbia has also fulfilled every request for assistance from the European Union since 2000, where Serbia can work together fully with ICTY, as an ad hoc international court formed under the UNSC Resolution, to create international peace and security in the Balkan region in general and in the country of Yugoslavia in particular.

The ongoing rule of Boris Tadic made Ratko Mladic worried about his arrest. It is worth mentioning that the fear was not worth the pressure of the international community on Boris Tadic for the attempt to arrest Ratko Mladic. The concern felt by Ratko Mladic was realized in a real way. He was arrested in the Lazarevo area on May 26, 2011, by Serbian police. Boris Tadic as President of Serbia immediately conveyed information to the public that Ratko Mladic had been arrested. This arrest was the result of the hard work of the Serbian government and its collaboration with ICTY as an ad hoc international judicial institution deliberately formed based on the UNSC Resolution, to arrest Ratko Mladic. Ratko Mladic was prosecuted for crimes committed in Bosnia. He was charged and tried for Ethnic massacre by the Panel of Judges in the ICTY.

The presence of ICTY was conceived to solve the problems that occurred in Yugoslavia in 1990-1995. Responding to the phenomena that occurred in Yugoslavia, ICTY was formed. ICTY was formed by the UN Security Council through Resolution No. 827 dated May 25, 1993. The formation of ICTY was carried out to try perpetrators of genocidal crimes that occurred in Yugoslavia. Besides that, the crime is also considered to have violated the provisions in International Humanitarian Law, namely in the form of grave breaches of the Geneva Conventions of 1949 (Article 2 of the ICTY Statute), violations of the law or customs of war (Article 3 of the ICTY Statute), Genocide (Article 4 of the ICTY Statute), crimes against humanity (Article 5 of the ICTY Statute). Before being arrested, Ratko Mladic was indicted on July 24 and November 16, 1995, and after his arrest in 2011, ICTY tried Ratko Mladic on May 16, 2012. In the trial process, Ratko 
Mladic filed 11 alleged crimes allegedly committed while serving as Staff Commander Main Army of the Republic of Bosnia-Serbia.

Jurisdiction in the capture of Ratko Mladic has existed since the Serbian collaboration with the ICTY. The ICTY has the authority to issue arrest warrants against international criminals, based on the completion of two indictments, namely genocide crimes and five counts of crimes against humanity. It was noted that the humanitarian crimes committed by Ratko Mladic consisted of murder, ill-treatment, deportation, and acts of forced separation of civilians, as well as inhumane. The lawsuit on the charges given by Ratko Mladic is following the case of Sarajevo, Srebrenica, and 15 cities in Bosnia-Herzegovina. In addition to having power, ICTY does not have a police force that has the authority to detain perpetrators of crimes against all charges. During the trial, Ratko Mladic was charged with various accusations and crimes he had committed. Ratko Mladic underwent a trial for 530 days during which in the trial all 500 witnesses were shown along with almost 10,000 items of evidence. With this criminal case, Ratko Mladic is known and labeled as "Bosnian Butcher". In this case, the ICTY panel of judges has sentenced a lifetime of conviction to the Bosnian Serb forces leader, Ratko Mladic, who was proven guilty of slaughtering ethnic Bosnian Muslims and all cases which incriminated him in the war that lasted from 1992 to 1995 in Yugoslavia (Harris, 2013).

\section{CONCLUSION}

The results conclude that the genocide that occurred against Bosnian Muslim ethnicity is one form of international crime while threatening international peace and security in the Balkan region, also intended to break the practice of impunity against international criminals who are a common enemy of humanity (hostis humanis generis). These two considerations form the legal basis for the issuance of the UNSC Resolution on the establishment of the International Criminal Tribunal for the former Yugoslavia (ICTY). The establishment of ICTY as an international court is intended as a court used to try perpetrators of genocidal crimes against Bosnian Muslim ethnicities, so that similar crimes will not be repeated in the future, both in Yugoslavia and in various other countries. As an ad hoc international tribunal, ICTY has carried out its judicial functions well, by prosecuting perpetrators of genocidal crimes against ethnic Bosnians in Yugoslavia, without being selective, even if the culprit was a President. ICTY was also working with local governments or international bodies to arrest the accused.

Before it was officially dissolved on December 21, 2017, ICTY had carried out its duties well in various cases that occurred within the territory of the country of Yugoslavia. The investigation and prosecution of the perpetrators of crimes ended with the record that almost all cases discussed legal issues related to gross human rights violations, especially the genocide crimes against ethnic Bosnians. ICTY has been present for 24 years as an ad hoc international judicial institution formed by the United Nations, wherevarious cases of gross human rights violations that occurred in Yugoslavia, have been appointed, investigated and the perpetrators are tried properly, to create justice and efforts to break the practice of impunity against perpetrators of international crimes who became a common enemy of humanity (hostis humanis generis). It highlights that legal instruments capable of mobilizing international support should have been designed in such a way as to reduce the threat of genocide.

\section{REFERENCES}

Allcock, J. B. (2000). Explaining Yugoslavia. Columbia University Press.

Arnold, J. R., \& Wiener, R. (Eds.). (2012). Cold War: the essential reference guide. ABC-CLIO.

Bassiouni, M. C. (2011). Crimes against humanity: historical evolution and contemporary application. Cambridge University Press.

Bergholz, M. (2013). Sudden nationhood: The microdynamics of intercommunal relations in Bosnia-Herzegovina after World War II. The American Historical Review, 118(3), 679-707. https://doi.org/10.1093/ahr/118.3.679

CIA. (2016). Yugoslavia : Key Question and Answer on the Debt Crisis. USA: Directorate of Confidential Intelligence 25X1.

Donia, R. (2014). The Article of Bosnian Genocide. Cambridge University Press

Fleming, C. M. (2016). Clausewitz's Timeless Trinity: A Framework for Modern War. Routledge. https://doi.org/10.4324/9781315572376

Genser, J., \& Ugarte, B. S. (Eds.). (2014). The United Nations Security Council in the Age of Human Rights. Cambridge University Press. https://doi.org/10.1017/CBO9781139626972

Gibbs, D. N. (2012). First do no harm: Humanitarian intervention and the destruction of Yugoslavia. Vanderbilt University Press.

Giorgetti, C. (2017). International Adjudicative Bodies, in Jacob Katz Cogan et al. (Eds.), The Oxford Handbook on International Organizations. Oxford: Oxford University Press.

Harding, C. (2007). 'Hostis Humani Generis'-The Pirate as Outlaw in the Early Modern Law of the Sea. In Pirates? The Politics of Plunder, 1550-1650 (pp. 20-38). Palgrave Macmillan, London. https://doi.org/10.1057/9780230627642 2

Harris, P. (2013). Democracy and deep-rooted conflict: options for negotiators. International Institute for Democracy and Electoral Assistance. 
Holbrooke, R. (2011). To End a War: The Conflict in Yugoslavia-America's Inside Story--Negotiating with Milosevic. Modern Library.

Horton, J. J., Milivojević, M., \& Allcock, J. B. (Eds.). (1998). Conflict in the Former Yugoslavia: An Encyclopedia. ABC-CLIO.

Huntington, S. P. (1996). The clash of civilizations and the remaking of world order. Simon \& Schuster.

Jessup, J. E. (1989). A chronology of conflict and resolution, 19451985. Greenwood.

Jones, A. (2013). Genocide and Crimes Against Humanity, in P. D. William (Ed), An Introduction Security Studies. London: Routledge

Koneska, C. (2014). After ethnic conflict: Policy-making in postconflict Bosnia and Herzegovina and Macedonia. Routledge.

McMahon, P. C. (2004). Rebuilding Bosnia: a model to emulate or to avoid?. Political Science Quarterly, 119(4), 569-593. https://doi.org/10.1002/j.1538-165X.2004.tb00530.x
Moffett, L. (2012). The role of victims in the international criminal tribunals of the Second World War. International Criminal Law Review, 12(2), 245-270. https://doi.org/10.1163/157181212X634153

Pavlović, D. (2019). Prospect theory and presidential elections: Two cases from Yugoslavia and Serbia. Communist and PostCommunist Studies, 52(1), 11-24. https://doi.org/10.1016/j.postcomstud.2019.01.002

Rodman, K. A. (2019). When Justice Leads, Does Politics Follow? The Realist Limits of Prosecutorial Agency in Marginalizing War Criminals. Journal of International Criminal Justice, 17(1), 13-44. https://doi.org/10.1093/jicj/mqz002

Schillings, S. (2016). Enemies of all humankind: fictions of legitimate violence. Dartmouth College Press. https://doi.org/10.26530/OAPEN 625275

Stavrianos, L. S. (2000). The Balkans since 1453. C. Hurst \& Co. Publishers.

https://doi.org/10.6000/1929-4409.2021.10.90

(C) 2021 Setiyono and Roisah; Licensee Lifescience Global.

This is an open access article licensed under the terms of the Creative Commons Attribution Non-Commercial License (http://creativecommons.org/licenses/by-nc/3.0/) which permits unrestricted, non-commercial use, distribution and reproduction in any medium, provided the work is properly cited. 